\title{
PENGARUH IKLIM ORGANISASI Dan KOMPETENSI Terhadap KINERJA PEGAWAI Pada KANTOR DINAS PERHUBUNGAN PROVINSI ACEH
}

\author{
Oleh: \\ Filia Hanum \\ Program Studi Manajemen \\ Fakultas Ekonomi Universitas Serambi Mekkah Banda Aceh \\ E-mail: \\ filiahanum2013@gmail.com
}

\begin{abstract}
This study aims to determine the effect of organizational climate and competence on employee performance at the Aceh Transportation Service office. The results of the study simultaneously that the organizational climate and competence have a significant effect on employee performance because the calculated $F_{\text {count }}$ is greater than the value of $F_{\text {table }}$, then $\mathrm{Ha}=$ accepted and $\mathrm{Ho}=$ rejected. Then partially each organizational climate variable and competency variable have a significant effect on employee performance because each variable has a $t_{\text {count }}$ greater than $t_{\text {table, }}$ $H_{a}=$ accepted and $H_{0}=$ rejected. Furthermore, the value of the correlation coefficient $(R)$ shows a value of 0.596 which indicates that the relationship between the independent variable and the dependent variable is positive.
\end{abstract}

Keywords: Organizational Climate, Competence and Employee Performance

\section{A. PENDAHULUAN}

Berbicara mengenai instansi pemerintahan atau perusahaan swasta tidak terlepas dari pada sumber daya manusia, karena instansi pemerintahan atau perusahaan swasta merupakan kumpulan orang-orang yang dipilih secara khusus untuk menjalankan tugas yang berbentuk pelayanan kepada orang banyak. Di era reformasi dan demokratisasi seperti sekarang ini, tuntutan masyarakat terhadap peningkatan kualitas pelayanan publik terutama dari instansi pemerintah semakin meningkat. Masyarakat berharap proses pelayanan yang diberikan oleh pemerintah dapat didapatkan dengan lebih mudah, sederhana, lancar, cepat, tepat, tidak berbelit-belit, ramah, manusiawi, terdapat kepastian dan kejelasan prosedur serta persyaratan pelayanan yang masuk akal. Instansi pemerintah terutama yang memberikan pelayanan harus terus menerus melakukan pembaharuan dan inovasi pelayanan oleh pegawainya yang merupakan tugasnya.

Untuk mencapai tujuan ini maka dibutuhkan iklim organisasi yang kondusif, di mana elemen yang satu dengan yang lain dapat menjalankan perannya. Dengan 
iklim organisasi maka akan mendorong terciptanya budaya kerja yang diharapkan mampu meningkatkan kinerja pegawai. Suasana lingkungan kerja yang dirasakan oleh masing-masing individu dalam sebuah organisasi sering disebut sebagai iklim organisasi (Arsan, 2016). Iklim organisasi terdiri dari campuran norma, nilai, harapan, kebijakan dan prosedur yang mempengaruhi motivasi kerja, komitmen dan akhirnya kinerja individu dan unit kerja. Iklim positif mendorong, sementara iklim negatif menghambat tujuan sebuah organisasi. Iklim organisasi mengacu pada kualitas kerja lingkungan hidup. Jika orang merasa dihargai di dalam organisasi, mereka cenderung melakukannya dan berkontribusi positif terhadap pencapaian hasil bisnis sebuah organisasi atau instansi (Rajaselvi, 2017).

Iklim organisasi yang dapat menunjang pencapaian tujuan semua pihak dalam sebuah perusahaan adalah harapan yang sangat ideal bagi perusahaan manapun. Penciptaan iklim hubungan karyawan dalam hal keyakinan, kepercayaan, dan keterbukaan merupakan produktifitas yang tinggi dan implementasi strategi organisasi yang efektif. Implikasi dari iklim organisasi seperti itu akan terwujud bilamana karyawan memiliki keyakinan yang tinggi dan percaya pada keadilan keputusan dan tindakan manajerial. Iklim organisasi yang kondusif memberikan rasa aman dan memungkinkan para pegawai untuk dapat berkerja optimal. Dibutuhkan iklim organisasi yang kondusif untuk menunjang pelaksanaan tugas karyawan. Iklim organisasi merupakan faktor yang penting dalam usaha peningkatan kinerja karyawan di suatu instansi pemerintahan maupun swasta (Robbins, 2015:355). Suatu organisasi haruslah mampu menyusun kebijakan yang tepat untuk mengatasi setiap perubahan yang akan terjadi. Keberhasilan penyusunan kebijakan yang menjadi perhatian adalah manajemen yang menyangkut pemberdayaan sumber daya manusia serta perlu adanya suatu iklim atau suasana yang bagus dalam organisasi sehingga mampu untuk berkompetensi (Jarwanto, 2014).

Faktor lain yang dapat berpengaruh terhadap kinerja pegawai adalah kompetensi. Kompetensi adalah suatu hal yang penting dimiliki oleh sumberdaya manusia di dalam dunia kerja. Ketika orang-orang yang berkerja dalam suatu instansi memiliki kompetensi yang sesuai dengan bidang pekerjaannya maka dia akan mampu baik dari segi pengetahuan, keterampilan, maupun mental dalam menjalankan pekerjaannya. Pengembangan sumber daya manusia pada dasarnya terdiri dari tiga variabel: kompetensi, komitmen dan budaya. Ini adalah konsep yang berorientasi pada sumber daya manusia yang berfokus pada pengembangan keterampilan, pengetahuan, dan kompetensi. Pengembangan sumber daya manusia dapat diterapkan baik di tingkat organisasi maupun di tingkat nasional, yang dapat didefinisikan sebagai "proses berkelanjutan untuk memastikan efektivitas pengembangan yang kompetensi, dinamika, dan motivasi karyawan secara sistematis dan terencana". Ini diperlukan untuk membuat fungsi organisasi dengan baik. Tanpa sumber daya yang berkompetensi, kinerja sebuah organisasi mungkin tidak bisa berkembang secara efektif atau efisien. Demikian juga halnya tanpa budaya yang tepat, organisasi juga tidak bisa bertahan lama (Rajaselvi, 2017).

Fathoni (2006:12) menyebutkan bahwa kinerja yang baik merupakan tujuan yang ingin dicapai oleh setiap organisasi. Kinerja suatu organisasi tidak dapat 
dilepaskan dari kinerja para pegawai dalam melaksanakan tugas dan tanggung jawabnya. Dengan demikian, maju atau tidaknya suatu organisasi sangat ditentukan oleh peran dan kualitas para pegawainya. Kinerja pegawai dikatakan meningkat dan semakin berkualitas apabila individu yang ada dalam organisasi berhasil mencapai standar kerja yang telah ditetapkan oleh organisasi dan dijadikan sebagai acuan penentu keberhasilan individu dalam bekerja. Dan hasil kerja yang dapat dicapai oleh seseorang atau sekelompok orang dalam organisasi, sesuai dengan wewenang dan tanggung jawab masing-masing dalam rangka upaya mencapai tujuan organisasi bersangkutan secara legal, tidak melanggar hukum dan sesuai dengan moral maupun etika (Fahmi, 2014:3).

Pelaksanaan tugas aparatur pemerintah khususnya pada Kantor Dinas Perhubungan Aceh dalam menghadapi tantangan otonomi daerah dibutuhkan iklim organisasi yang kondusif untuk menunjang pelaksanaan tugas aparat. Iklim organisasi merupakan faktor yang penting dalam usaha peningkatan kinerja aparatur pemerintah. Iklim organisasi yang kondusif akan berpengaruh pada motivasi pegawai, yang akan mendorong kepuasan kerja dan kinerja para pegawai.

\section{B. KAJIAN PUSTAKA}

\section{Iklim Organisasi}

Iklim organisasi merupakan faktor penting yang menentukan kehidupan suatu organisasi. Seperti yang dikemukakan oleh Gibson et al. (2006) (dalam Zulkiram, 2013) bahwa iklim organisasi adalah sifat lingkungan kerja atau lingkungan psikologis dalam organisasi yang dirasakan oleh para pekerja atau anggota organisasi dan dianggap dapat mempengaruhi sikap dan perilaku pekerja terhadap pekerjaannya. Gilmer (1961:49) (dalam Setiawan, 2015) mendefinisikan iklim organisasi merupakan karakteristik-karakteristik tertentu yang membedakan suatu organisasi dengan organisasi lainnya dan mempengaruhi tingkah laku manusia di dalam organisasi tersebut. Gilmer menguraikan bahwa iklim organisasi tidak hanya mempengaruhi tingkah laku individu-individu dalam organisasi, tetapi juga bagaimana organisasi tersebut berinteraksi dengan yang lain. Iklim organisasi merupakan suatu perangkat manajemen yang efektif untuk memadukan motivasi individu dengan tujuan serta tugas-tugas dalam organisasi. Dari seluruh definisi tersebut dapat disimpulkan bahwa definisi iklim organisasi adalah, persepsi anggota organisasi baik individu maupun kelompok dan pihak lain yang berhubungan dengan organisasi (misalnya: supplier, nasabah, konsultan, dan lain-lain) secara rutin tentang lingkungan internal organisasi yang akan mempengaruhi sikap dan perilaku anggota organisasi, serta menentukan kinerja organisasi.

\section{Kompetensi}

Kompetensi mempunyai arti yang sama dengan kata kemampuan, kecakapan atau keahlian. Rofiatun (2011) menyatakan bahwa kompetensi dalam suatu situasi tidak dapat digunakan untuk memperkirakan kompetensi dalam situasi lain. Dari pendapat tersebut dapat dipahami bahwa kompetensi menunjuk pada kinerja seseorang dalam suatu pekerjaan yang bisa dilihat dari pikiran, sikap, 
dan perilaku. Begitu juga Robbins (2015:249) menjelaskan konsep kompetensi sebagai gabungan dari bakat (aptitude) dan kemampuan (ability). Bakat menunjukkan kapabilitas untuk belajar sesuatu dan sifatnya potensial. Untuk kemampuan merujuk pada kapasitas individu untuk mengerjakan berbagai tugas dalam suatu pekerjaan. Kemampuan dibina oleh pengetahuan dan keterampilan. Penentuan tingkat kompetensi dibutuhkan agar dapat mengetahui tingkat kinerja yang diharapkan untuk mendapatkan nilai baik atau rata-rata. Penentuan ambang kompetensi yang dibutuhkan tentunya akan dapat dijadikan dasar bagi proses seleksi, suksesi perencanaan evaluasi kinerja dan pengembangan sumber daya manusia. Dengan demikian, kompetensi menunjukkan keterampilan atau pengetahuan yang dicirikan oleh profesionalisme dalam suatu bidang tertentu sebagai sesuatu yang terpenting dan memiliki keunggulan dalam bidang tersebut. Adapun indikator yang digunakan di dalam variabel ini adalah pengetahuan, keterampilan, perilaku dan tanggung jawab (Maleha, 2013).

\section{Kinerja Pegawai}

Menurut As'ad (1995) (dalam Sudaryono, 2017:67) kinerja pada umumnya diartikan sebagai kesuksesan seseorang dalam melaksanakan suatu pekerjaan. Kinerja pegawai merupakan hasil kerja yang dicapai seseorang dalam melaksanakan tugas-tugas yang dibebankan kepadanya untuk mencapai target kerja. Pegawai dapat bekerja dengan baik bila memiliki kinerja yang tinggi sehingga dapat menghasilkan kerja yang baik. Kinerja pegawai merupakan salah satu faktor penentu keberhasilan organisasi dalam mencapai tujuannya. Untuk itu kinerja dari para pegawai harus mendapat perhatian dari para pimpinan organisasi, sebab menurunnya kinerja dari pegawai dapat mempengaruhi kinerja organisasi secara keseluruhan.

\section{METODE PENELITIAN}

Objek dalam penelitian ini adalah iklim organisasi dan kompetensi sebagai variabel bebas atau independent serta kinerja pegawai sebagai variabel terikat atau dependent. Penelitian dilakukan pada Kantor Dinas Perhubungan Aceh yang beralamat di Jln. Mayjend. T. Hamzah Bendahara No. 52, Kuta Alam, Kota Banda Aceh. Metode yang dilakukan dalam penelitian ini adalah metode deskriptif dan verifikatif dengan pendekatan kuantitatif karena penulis ingin mendeskripsikan pengaruh iklim organisasi dan kompetensi terhadap kinerja pegawai.

\section{Populasi dan Sampel}

Dalam penelitian ini populasi yang digunakan adalah seluruh pegawai pada Kantor Dinas Perhubungan Aceh berjumlah 214 orang. Dari jumlah populasi tersebut dengan menggunakan metode Slovin dan diambil sebesar 10\%, maka jumlah sampel ditentukan sebesar 68 orang pegawai di mana sampel penelitian adalah objek yang diteliti dan dianggap mewakili seluruh populasi. Untuk memperoleh data dan keterangan yang diperlukan, penulis menggunakan alat pengumpulan data melalui penelitian lapangan (field research). Data yang 
diperoleh merupakan data primer yang didapatkan dengan cara: a) Observasi, b) Wawancara, c) Kuesioner, d) Dokumentasi.

\section{Teknik Analisis Data}

\section{Uji Asumsi Klasik}

Untuk memperoleh model persamaan regresi yang baik, maka terhadap model persamaan regresi yang terbentuk perlu dilakukan beberapa uji asumsi yaitu:

\section{a. Uji Normalitas}

Uji normalitas untuk mengetahui apakah data yang digunakan berdistribusi normal atau tidak. Pengujian ini dilakukan dengan mengamati histogram atas nilai residual dan grafik normal probability plot. Deteksi dengan melihat penyebaran data (titik) pada sumbu diagonal dari grafik. Dasar pengambilan keputusan, jika data menyebar di sekitar garis diagonal dan mengikuti arah garis diagonal, maka model regresi memenuhi asumsi normalitas dan jika data menyebar jauh dari arah diagonal dan/atau tidak mengikuti arah garis diagonal, maka model regresi tidak memenuhi asumsi normalitas.

\section{b. Uji Heteroskedastisitas}

Heteroskedastisitas bertujuan untuk menguji apakah dalam model regresi, terjadi ketidaksamaan varians residual dari satu pengamatan ke pengamatan lain. Jika varians tetap, maka disebut homoskedastisitas.Dan jika varians berbeda disebut heteroskedastisitas. Model regresi yang baik adalah tidak terjadi heteroskedastisitas. Untuk mendeteksi adanya heteroskedastisitas dilakukan dengan melihat ada tidaknya pola tertentu pada grafik, di mana sumbu $\mathrm{X}$ adalah $\mathrm{Y}$ yang telah diprediksi, dan sumbu $\mathrm{X}$ adalah residual $\left(\mathrm{Y}_{\text {prediksi }}-\mathrm{Y}_{\text {sesungguhnya }}\right)$ yang telah di studentized. Dasar pengambilan keputusan:

a) Jika ada pola tertentu, seperti titik-titik (points) yang ada membentuk suatu pola tertentu yang teratur (bergelombang, melebar kemudian menyempit), maka telah terjadi heteroskedastisitas.

b) Jika tidak ada pola yang jelas, serta titiktitik menyebar diatas dan dibawah angka 0 pada sumbu $Y$, maka tidak terjadi heteroskedastisitas.

\section{c. Uji Multikolinearitas}

Uji Multikolinearitas bertujuan untuk menguji apakah dalam model regresi ditemukan adanya korelasi antar variable bebas (independen variabel). Model regresi yang baik seharusnya tidak terjadi korelasi diantara variabel bebas.Untuk menguji adanya multikolinearitas yaitu dengan melihat pada Tolerance Value atau Variance Inflation Faktor (VIF). Pedoman suatu model regresi yang bebas multikolinearitas adalah mempunyai VIF di sekitar angka 1, sedangkan batas VIF adalah 10 dan mempunyai angka dan mempunyai toleransi mendekati 1 . 


\section{HASIL Dan PEMBAHASAN}

\section{Uji Validitas dan Reliabilitas}

\section{Hasil Uji Validitas}

Di dalam penelitian ini pengujian validitas data dilakukan secara statistik, yaitu dengan menggunakan uji Pearson product-moment Coeffisient of Correlation dengan bantuan software komputer melalui program Statistic Packege for Sosial Sciensin (SPSS) IBM 22. Berdasarkan hasil pengolahan data (terlampir) seluruh item pertanyaan dinyatakan valid karena memiliki nilai signifikansi di bawah $5 \%$, yaitu dengan membandingkan seluruh pertanyaan $r_{\text {hitung }}$ dengan $r_{\text {tabel }}$ produck moment. Apabila $\mathbf{r}_{\text {hitung }}>\mathrm{r}_{\text {tabel }}$ maka item pertanyaan dinyatakan valid. Sehingga pertanyaan-pertanyaan tersebut adalah signifikan atau konsisten, artinya data yang diperoleh dapat dipergunakan untuk penelitian. Mengenai hasil pengujian validitas dapat dilihat pada Tabel 1 .

Tabel 1

\section{Hasil Uji Validitas}

\begin{tabular}{|c|c|c|c|c|c|}
\hline No & Variabel & $\begin{array}{c}\text { Butir } \\
\text { Pernyataan }\end{array}$ & Nilai $\mathbf{r}_{\text {hitung }}$ & $\begin{array}{c}\text { Nilai } \mathbf{r}_{\text {tabel }} \\
(\mathbf{N}=68)\end{array}$ & Keterangan \\
\hline 1 & $\begin{array}{l}\text { Iklim Organisasi } \\
\qquad\left(\mathrm{X}_{1}\right)\end{array}$ & $\begin{array}{l}\text { A } 1 \\
\text { A } 2 \\
\text { A } 3 \\
\text { A } 4\end{array}$ & $\begin{array}{l}0,469 \\
0,594 \\
0,655 \\
0,339\end{array}$ & 0,235 & Valid \\
\hline 2 & $\begin{array}{l}\text { Kompetensi } \\
\qquad\left(\mathrm{X}_{2}\right)\end{array}$ & $\begin{array}{ll}\text { B } 1 \\
\text { B } 2 \\
\text { B } 3 \\
\text { B } 4\end{array}$ & $\begin{array}{l}0,352 \\
0,477 \\
0,591 \\
0,622\end{array}$ & 0,235 & Valid \\
\hline 3 & $\begin{array}{c}\text { Kinerja Pegawai } \\
\text { (Y) }\end{array}$ & $\begin{array}{l}\text { C } 1 \\
\text { C } 2 \\
\text { C } 3 \\
\text { C } 4\end{array}$ & $\begin{array}{l}0,413 \\
0,329 \\
0,635 \\
0,577\end{array}$ & 0,235 & Valid \\
\hline
\end{tabular}

Sumber: data primer yang diolah

Berdasarkan Tabel 1 menunjukkan besarnya koefisien korelasi antara tiaptiap item dengan total item untuk instrumen iklim organisasi, kompetensi dan kinerja pegawai. Adapun besarnya koefisien dari item untuk instrumen iklim organisasi adalah berkisar antara 0,339-0,655, koefisien dari item untuk instrumen kompetensi adalah berkisar antara 0,352-0,622, sedangkan instrumen kinerja pegawai menunjukkan angka berkisar 0,329-0,635. Karena nilai $\mathrm{r}_{\text {hitung }}$ dari variabel-variabel tersebut lebih besar dari nilai $r_{\text {tabel }}$ yaitu 0,235. Sehingga dapat diartikan bahwa seluruh pertanyaan yang berhubungan dengan ketiga variabel tersebut (iklim organisasi, kompetensi dan kinerja pegawai) dinyatakan valid.

\section{Hasil Pengujian Reliabilitas}

Pengujian reliabilitas digunakan untuk mengukur apakah alat pengumpulan data telah menunjukkah tingkat ketepatan, keakuratan atau konsentrasi alat tersebut dalam mengungkapkan gejala tertentu dari sekelompok individual. Untuk menguji keadaan kuisioner yang digunakan, maka penelitian ini menggunakan uji 
reliabilitas. Analisis yang digunakan untuk mentafsirkan korelasi antara skala yang dibuat dengan skala variabel yang ada. Hasil uji reliabilitas untuk variabel dependen dan variabel independen juga menunjukkan hasil yang reliabel. Nilai Cronbach Alpha yang dihasilkan > 0.5, sehingga variabel iklim organisasi, kompetensi dan kinerja pegawai yang digunakan dinyatakan reliabel.

Tabel 2 menunjukkan hasil dari output komputer program IBM Statistic Package for Sosial Science (SPSS) 22 mengenai uji reliabilitas untuk iklim organisasi, kompetensi dan kinerja pegawai.

Tabel 2

Pengujian Reliabilitas Butir-Butir Variabel Penelitian

\begin{tabular}{|c|c|c|c|}
\hline Variabel & $\begin{array}{c}\text { Alpha Cronbach } \\
\text { Hitung }\end{array}$ & $\begin{array}{c}\text { Alpha Cronbach } \\
\text { yang disyaratkan }\end{array}$ & Keterangan \\
\hline $\begin{array}{c}\text { Iklim Organisasi } \\
\left(\mathrm{X}_{1}\right)\end{array}$ & 0,584 & 0,50 & Reliabel \\
\hline $\begin{array}{c}\text { Kompetensi } \\
\left(\mathrm{X}_{2}\right)\end{array}$ & 0,564 & 0,50 & Reliabel \\
\hline $\begin{array}{c}\text { Kinerja Pegawai } \\
(\mathrm{Y})\end{array}$ & 0,614 & 0,50 & Reliabel \\
\hline
\end{tabular}

Berdasarkan Tabel 2 dapat diketahui bahwa hasil perhitungan Alpha Cronbach adalah 0,584 untuk instrumen pengukuran iklim organisasi, nilai dari instrumen kompetensi memiliki bobot adalah 0,564, dan nilai dari instrumen kinerja pegawai memiliki bobot adalah 0,614. Dengan demikian dapat diambil kesimpulan bahwa nilai total dari masing-masing tiga variabel tersebut adalah reliabel.

\section{Hasil Analisis Regresi Linier Berganda}

Tabel 3

Hasil Analisis Regresi Linier Berganda

\begin{tabular}{|c|c|c|c|c|c|c|c|}
\hline \multirow[t]{2}{*}{ Variable } & \multicolumn{2}{|c|}{$\begin{array}{l}\text { Unstandardized } \\
\text { Coefficients }\end{array}$} & \multirow{2}{*}{$\begin{array}{c}\begin{array}{c}\text { Standardized } \\
\text { Coefficients }\end{array} \\
\text { Beta }\end{array}$} & \multirow[t]{2}{*}{$\mathbf{T}$} & \multirow[t]{2}{*}{ Sig. } & \multicolumn{2}{|c|}{$\begin{array}{c}\text { Collinearity } \\
\text { Statistics }\end{array}$} \\
\hline & B & Std. Error & & & & Tolerance & VIF \\
\hline 1 (Constant) & 13.218 & 3.304 & & 4.001 & .000 & & \\
\hline $\begin{array}{l}\text { Iklim } \\
\text { Organisasi }\end{array}$ & .107 & .125 & .101 & 2.860 & .003 & .936 & 1.069 \\
\hline Kompetensi & .356 & .117 & .358 & 3.038 & .003 & .936 & 1.069 \\
\hline
\end{tabular}

Berdasarkan hasil dari Tabel 3, dapat disimpulkan persamaan regresi untuk Kinerja Pegawai adalah sebagai berikut:

$$
\text { Kinerja Pegawai }=13,218+0,107 \mathrm{X}_{1}+0,356 \mathrm{X}_{2}+e_{i}
$$




\section{Hasil Uji Hipotesis}

\section{Tabel 4}

Uji Hipotesis

\begin{tabular}{cllll}
\hline \multirow{2}{*}{ Bentuk Pengujian } & \multicolumn{2}{c}{ Nilai Statistik } & \multirow{2}{*}{ Keterangan } \\
\cline { 2 - 3 } & $\mathrm{F}_{\text {Hitung }}$ & $\mathrm{F}_{\text {Tabel }}$ & \\
\hline \hline Pengujian secara simultan & 6,039 & 2,352 & Hipotesis diterima \\
Pengujian secara parsial & $\mathrm{t}_{\text {hitung }}$ & $\mathrm{t}_{\text {tabel }}$ & \\
\hline \hline 1 & Iklim Organisasi & 2,860 & 1,995 & Hipotesis diterima \\
2 & Kompetensi & 3,038 & 1,995 & Hipotesis diterima \\
\hline \multicolumn{2}{l}{ Sumber: data primer yang diolah, Output SPSS } & \multicolumn{2}{l}{$l$}
\end{tabular}

Berdasarkan hasil uji hipotesis pada Tabel 4 dapat dilihat bahwa:

1. Secara simultan iklim organisasi dan kompetensi berpengaruh signifikan terhadap kinerja pegawai, karena hasil pengujian statistik yang didapat menunjukkan nilai $\mathrm{F}_{\text {hitung }}$ sebesar 6,039 lebih besar dari nilai $\mathrm{F}_{\text {tabel }}$ sebesar 2,352. Dengan demikian berdasarkan probabilitas/signifikan disimpulkan bahwa: $\mathrm{H}_{\mathrm{a}}=$ diterima dan $\mathrm{H}_{0}=$ ditolak. Dapat disimpulkan bahwa hipotesis yang diajukan yaitu diduga iklim organisasi dan kompetensi mempunyai hubungan positif dengan kinerja pegawai terbukti kebenarannya.

2. Secara parsial variabel iklim organisasi berpengaruh signifikan terhadap kinerja pegawai, karena hasil pengujian statistik yang didapat menunjukkan nilai $\mathrm{t}_{\text {hitung }}$ sebesar 2,860 lebih besar dari nilai $\mathrm{t}_{\text {tabel }}$ sebesar 1,995. Dengan demikian berdasarkan probabilitas/signifikan disimpulkan bahwa: $\mathrm{H}_{\mathrm{a}}=$ diterima dan $\mathrm{H}_{0}=$ ditolak. Dapat disimpulkan bahwa hipotesis yang diajukan yaitu diduga iklim organisasi mempunyai hubungan positif dengan kinerja pegawai terbukti kebenarannya.

3. Secara parsial variabel kompetensi berpengaruh signifikan terhadap kinerja pegawai, karena hasil pengujian statistik yang didapat menunjukkan nilai $t_{\text {hitung }}$ sebesar 3,038 lebih besar dari nilai $\mathrm{t}_{\text {tabel }}$ sebesar 1,995. Dengan demikian berdasarkan probabilitas/signifikan disimpulkan bahwa: $\quad \mathrm{H}_{\mathrm{a}}=$ diterima dan $\mathrm{H}_{0}=$ ditolak. Dapat disimpulkan bahwa hipotesis yang diajukan yaitu diduga kompetensi mempunyai hubungan positif dengan kinerja pegawai terbukti kebenarannya.

\section{Hasil Koefisien Korelasi (R) dan Determinasi $\left(\mathbf{R}^{2}\right)$}

\section{Tabel 5}

Koefisien Korelasi dan Determinasi

Model Summary ${ }^{b}$

Model R R Square Adjusted R Square Std. Error of the Estimate Durbin-Watson

\begin{tabular}{cccccc} 
Model & $\mathbf{R}$ & R Square & Adjusted R Square & Std. Error of the Estimate & Durbin-Watson \\
\hline \hline 1 & $.596^{\mathrm{a}}$ & .757 & .331 & .998 & .838 \\
\hline
\end{tabular}

a. Predictors: (Constant), Kompetensi, Iklim Organisasi

b. Dependent Variable: Kinerja Pegawai

Berdasarkan Tabel 5 nilai koefisien korelasi (R) menunjukkan nilai sebesar 0,596 yang menandakan bahwa hubungan antara variabel independen 
dengan variabel dependen adalah positif karena memiliki nila $\mathrm{R}>0,5$. Adapun nilai koefisien determinasi $\left(\mathrm{R}^{2}\right)$ sebesar 0,757 menunjukkan bahwa hanya sebesar $75,7 \%$ variasi variabel dependen (kinerja pegawai) yang dapat dijelaskan oleh variasi variabel independen (iklim organisasi dan kompetensi) dalam penelitian ini. Sedangkan sisanya yang sebesar $24,3 \%$ dijelaskan oleh variabel lain yang tidak dimasukkan ke dalam penelitian yang mungkin dapat mempengaruhi kinerja pegawai.

\section{E. KESIMPULAN Dan SARAN}

\section{Kesimpulan}

Berdasarkan hasil penelitian dan pembahasan, maka dapat disimpulkan bahwa baik secara simultan maupun parsial iklim organisasi dan kompetensi berpengaruh signifikan terhadap kinerja pegawai, karena hasil pengujian statistik yang didapat menunjukkan bahwa baik nilai $\mathrm{F}_{\text {hitung }}$ maupun nilai $\mathrm{t}_{\text {hitung }}$ samasama lebih besar dari nilai $\mathrm{F}_{\text {tabel }}$ dan $\mathrm{t}_{\text {tabel }}$. Dengan demikian berdasarkan probabilitas/signifikan disimpulkan bahwa: $\mathrm{H}_{\mathrm{a}}=$ diterima dan $\mathrm{H}_{0}=$ ditolak. Hal ini menunjukkan bahwa tinggi rendahnya tingkat iklim organisasi dan kompetensi karyawan akan mempengaruhi peningkatkan kinerja karyawan pada kantor Dinas Perhubungan Aceh. Dengan kata lain semakin tinggi iklim organisasi dan kompetensi dari karyawan maka akan berakibat meningkatnya kinerja karyawan pada kantor Dinas Perhubungan Aceh. Selanjutnya nilai koefisien korelasi (R) menunjukkan nilai sebesar 0,596 yang menandakan bahwa hubungan antara variabel independen dengan variabel dependen adalah positif karena memiliki nilai $\mathrm{R}>0,5$.

\section{Saran}

Mengingat faktor iklim organisasi dan kompetensi sangat diperlukan dalam meningkatkan kinerja pegawai, maka dengan ini disarankan kepada Pimpinan Kantor Dinas Perhubungan Aceh untuk lebih meningkatkan kompetensi pegawai khususnya keterampilan baik melalui seminar/workshop, kursus, dan pelatihan terkait untuk meningkatkan kinerja pegawai, sebab dalam dunia kerja sehari-hari kompetensi keterampilan dan kompetensi pengetahuan lebih diutamakan. Selain itu disarankan agar iklim organisasi dalam bekerja juga harus dapat lebih diperbaiki seperti halnya peningkatann motivasi dan disiplin kerja sehingga bisa meningkatkan motivasi kerja pegawai. 


\section{DAFTAR PUSTAKA}

Arsan. (2016). Pengaruh Iklim Organisasi, Pendidikan dan Budaya Kerja Terhadap Kinerja Pegawai Negeri Sipil (PNS) pada Kantor Kecamatan Bahodopi Kabupaten Morowali . e Jurnal Katalogis, Vol.4, No.8, ISSN: 2302-2019, Agustus , 148-155.

Berberoglu, A. (2018). Impact of Organizational Climate on Organizational Commitment and Perceived Organizational Performance : Empirical Evidence from Public Hospitals. Barberoglu BMC Health Service Research, Nicosia, Cyprus, 18:399, 1-9.

Bhat, S. A., \& Bashir, H. (2016). Influence of Organizational Climate on Job Performance of Teaching Professionals: An Empirical Study. International Journal of Education and Management Studies, 6(4), ISSN (p):2231-5632, ISSN (e) : 2321-3671, Punjab , 445-448.

Dewi, E. N. (2017). Pengaruh Iklim Organisasi dan Kompetensi Pegawai Terhadap Kinerja Pegawai dalam Mewujudkan Mutu Pelayanan Kesehatan. Jurnal Publik, Vol. 11, No. 1, 89-100.

Fahmi, I. (2014). Etika Bisnis (Teori, Kasus dan Solusi). Cetakan Kedua Februari. Bandung: Alfabeta .

Fathoni, A. (2006). Manajemen Sumber Daya Manusia. Cetaka Pertama Januari. Jakarta: Rineka Cipta.

Haq, F. U. (2018). Pengaruh Iklim Organisasi dan Kompetensi Terhadap Kinerja Karyawan (Studi pada AJB Bumiputra 1912 Kantor Wilayah Surabaya. Jurnal Ilmu Manajemen, Vol. 6, No.1 , 1-7.

Jarwanto. (2014). Analisis Pengaruh Iklim Organisasi dan Motivasi Terhadap Kinerja Pegawai Badan Pusat Statistik Provinsi Daerah Istimewa Yogyakarta . JBTI, Vol. 5, No.2, Oktober, 246-259.

Maleha, N. Y. (2013). Analisis Pengaruh Kompetensi, Disiplin Kerja dan Iklim Kerja Terhadap Kinerja Karyawan Universitas Indo Global Mandiri (UIGM) Palembang. 1-14.

Maulidani, F. (2012). Pengaruh Iklim Organisasi dan Kompetensi Karyawan Terhadap Kinerja Karyawan pada KSP Nasari Cabang Bandung. Bandung : Fakultas Ekonomi Program Studi Manajemen, Unuversitas Komputer Indonesia.

Pasaribu, S. E., \& Kariono. (2014). Pengaruh Iklim Organisasi Terhadap Kinerja Pegawai pada Biro Rektor Universitas Muhammadiyah Tapanuli Selatan. Jurnal Administrasi Publik (JAP), Vol.2, o.2, ISSN: 2088-527x , 177-195.

Rajaselvi, S., \& Sundaran, A. S. (2017). Impact of HRM Competencies, Organizational Culture, Organizational Climate on Employee Performance (A study with Reference to Puducherry IT Companies). International Journal of Innovative Research in Science, Engineering, and Technology 
(IJIRSET), Vol.6, Issue 6, June, ISSN (online): 2319-8753, ISSN (print): 2347-6710, 11593-11600.

Robbins, S. P., \& Judge, T. A. (2015). Perilaku Organisasi. Edisi 16. Jakarta: Salemba Empat.

Rofiatun, \& Masluri. (2011). Pengaruh Iklim Organisasi dan Kompetensi Pegawai Terhadap Kinerja Pegawai dengan Mediasi Motivasi pada Dinas-dinas Di Kabupaten Kudus. Analisis Manajemen, Vol. 5, No.1, Juli, ISSN: 14411$1799,1-15$.

Setiawan, K. C. (2015). Pengaruh Iklim Organisasi Terhadap Kinerja Karyawan Level Pelaksana Di Divisi Operasi PT PUSRI Palembang. PSIKIS. Jurnal Psikologi Islami, Vol.1, No.1, ISSN: 2502-728X, 23-32.

Sudaryono. (2017). Pengantar Manajemen (Teori dan Kasus). Cetakan 1. Yogyakarta: CAPS.

Widyatmini, \& Hakim, L. (2008). Hubungan kepemimpinan, Kompensasi dan Kempetensi Terhadap Kinerja Pegawai Dinas Kesehatan Kota Depok . Jurnal Ekonomi Bisnis, Vol.13, No.2, Agustus , 163-171.

Winanti, M. B. (2014). Pengaruh Kompetensi Terhadap Kinerja Karyawan (Survei pada PT Frisian Flag Indonesia Wilayah Jawa Barat). BandungJawa Barat: Majalah Ilmiah UNIKOM Bidang Humaniora, Vol. 7, No.2, Universitas Komputer Indonesia.

Zulkiram, Yunus, M., \& Amri. (2013). Pengaruh Iklim Organisasi, Disiplin Kerja dan Kompensasi Terhadap Kinerja Pegawai Serta Dampaknya pada Kinerja Lembaga Pemasyarakatan Klas IIA Banda Aceh. Jurnal Manajemen Pascasarjana Universitas Syiah Kuala, Vol.2, No.1, November, ISSN: 2302-0199, 128-137 